\title{
The Effect of Ethanolic Extract of Roselle (Hibiscuss sabdariffa L) on Increasing SOD Activity
}

\author{
Abdul Rahman W, Nurkhasanah, Nanik Sulistyani \\ Postgraduate programe of Natural Drugs and Cosmetics, Faculty of Pharmacy, \\ Universitas Ahmad Dahlan, Yogyakarta, Indonesia
}

\begin{abstract}
Article Info
Article history:

Received Dec 10, 2015

Revised Jan 16, 2016

Accepted Feb 26, 2016

\section{Keyword:}

Antioxidant

DMBA

Hibiscus sabdariffa L

SOD

ABSTRACT

Free radicals were reactive species caused oxidation of lipids membrane and DNA. Superoxide dismutase (SOD) is one of the primary antioxidants to inhibit free radicals. The purpose of this study was to determine the effect of ethanol extract of Roselle calyx on SOD enzyme activity of the Sprague Dawley (SD) rats induced by 7.12-dimethylbenzen[a]anthracene (DMBA). The animals age of four weeks divided in to five groups, groups I were normal group. Group II is the negative control group only induced by DMBA $75 \mathrm{mg} / \mathrm{kgBW}$; and group III ,IV ,and V were treatment groups that treated by ethanolic extract of Roselle calyx at dose of 10,50 and $100 \mathrm{mg} / \mathrm{kgBW} / \mathrm{day}$ for 7 days. After treatment with roselle, animals were induced by DMBA 75 $\mathrm{mg} / \mathrm{kgBW}$. On day 8 after DMBA induction, animals were fasted for 16 hours and blood was collected to measured SOD activity. Data were analyzed using One Way Analysis of Variance (ANOVA) and LSD (P $<0.05)$. The result showed the significancies on increasing of SOD activity at $10 \mathrm{mg} / \mathrm{kgBW}(50.87 \pm 1.98), 50 \mathrm{mg} / \mathrm{kgBW}(69.98 \pm 3.58)$ and $100 \mathrm{mg} / \mathrm{kgBW}$ (73.01 \pm 6.95$)$ compared with DMBA $(43.74 \pm 1.95)(\mathrm{p}<0,05)$.
\end{abstract}

Copyright $@ 2016$ Institute of Advanced Engineering and Science. All rights reserved.

\section{Corresponding Author:}

Nurkhasanah,

Lecturer of Postgraduate Program,

Faculty of Pharmacy, Ahmad Dahlan University,

Jl. Prof. Dr. Soepomo, S.H. Janturan, Warungboto, Umbulharjo, Yogyakarta, 55164.

Email: Ibufathan@yahoo.com

\section{INTRODUCTION}

The human body naturally has a process of formation free radicals as products of metabolic processes [1]. Free radicals including reactive oxygen species (ROS) and reactive nitrogen species (RNS) in the body can lead to degenerative diseases such as neurodegenerative, aging and cancer [2]. Reactive oxygen compounds are produced in vivo include superoxide radical $(\mathrm{O} 2-)$ and hydrogen peroxide $\left(\mathrm{H}_{2} \mathrm{O}_{2}\right)$ is a compound that can cause lipid peroxidation and DNA damage in the cells [3].

This study was conducted to determine the SOD antioxidant activity of ethanol extract of roselle calyx in Sprague Dawley rats induced by 7,12-dimethylbenzen[a]anthracene (DMBA), DMBA is one of the free radicals is compounds. Free radicals could be produced by cigarette smoke, car fumes and kitchen smoke [4].

Roselle (Hibiscus sabdariffa L.) is reported to have potential as antioxidants. The active substance in Roselle (Hibiscus sabdariffa L.) which function a key role as antioxidants were gossypetin, anthosianin, hibiscine glucoside [5]. 


\section{RESEARCH METHOD}

\subsection{Materials}

Roselle calyx (Hibiscus sabdariffa L.) were obtained from Malang, East Java. The animal used is the male rats of Sprague Dawley (SD), age 4 to 6 weeks with an average weight of 50 gram.

\subsection{Ekstractions}

Simplisia dried in oven at a temperature of $50-60{ }^{\circ} \mathrm{C}$ and grounded to get a powder. The powder was then sieved using a sieve no.20). Roselle calyx (Hibiscus sabdariffa L.) were extracted with ethanol $70 \%$ (1:5) using the method of maceration with stirring for 1 hour, then left in place for up to 24 hours. Maserat separated and filtered using a flannel cloth. Maserat evaporated with a rotary vacuum evaporator at $60^{\circ} \mathrm{C}$ and $100 \mathrm{rpm}$, then concentrated on water bath with a temperature of $60-70^{\circ} \mathrm{C}$ to obtain a concentrate extract. Ethanolic extract of Roselle calyx (Hibiscus sabdariffa L.) were weighed and the yield is calculated.

\subsection{Experimentals}

The animals with 4 to 6 weeks divided into five groups, group I was normal group. Group II was the negative control group only induced by DMBA $75 \mathrm{mg} / \mathrm{kgBW}$; and group III, IV, and V were treatment groups that treated by ethanolic extract of roselle calyx at dose of 10,50 , and $100 \mathrm{mg} / \mathrm{kgBW} / \mathrm{day}$ for 7 days. After treatment with rosella, animals were induced by DMBA $75 \mathrm{mg} / \mathrm{kgBW}$. On day 8 after DMBA induction, animals were fasted for 16 hours and blood was collected to measured SOD activity. Data were analyzed using One Way Analysis of Variance (ANOVA) and LSD (P <0.05).

\subsection{Determining SOD Activity}

SOD enzyme activity determined by Wijeratne et al., (2005) method [6]. Total of $0.06 \mathrm{ml}$ of the supernatant blood was reacted with a mixture consisting of $2.70 \mathrm{ml}$ of $50 \mathrm{Mm}$ sodium carbonate buffer containing $0.1 \mathrm{mM}$ EDTA (pH 10), $0.06 \mathrm{ml}$ of xanthine $10 \mathrm{Mm}, 0.03 \mathrm{ml}$ of bovine serum albumin (BS) $0.5 \%$, and $0.03 \mathrm{ml}$ of $2.5 \mathrm{mM}$ NBT. Furthermore, the addition of xanthine oxidase (0:04 units). The absorbance after 30 minutes was measured at wavelength of $560 \mathrm{~nm}$. As used control solution used in sample preparation hearts that PBS containing $11.5 \mathrm{~g} / \mathrm{L} \mathrm{KCl}$. SOD activity (\%) was calculated using the following equation:

Notes : A (Sample Absorbace)

$$
(1-(\mathrm{A} / \mathrm{B})) \times 100 \%
$$

B (Control Absorbance)

\subsection{Data Analysis}

Data results of SOD enzyme activity in the form of numerical data as outlined in the mean \pm SD, followed by statistical tests using ANOVA followed by LSD test $(\mathrm{P}<0.05)$.

\section{RESULTS AND ANALYSIS}

\subsection{Determination of SOD activity in Spraguey dawley rats-induced DMBA}

The superoxide dismutase (SOD) is one of the antioxidant enzymes produced in the body and has a very important role because it is the first antioxidant enzyme that arrested free radicals to enter the body. The SOD catalyzes metabolism of superoxide radical $\left(\mathrm{O}_{2}^{-}\right)$into hydrogen peroxide and oxygen [7]. The activity of SOD in the DMBA induced rat treated by DMBA were performed in the Table 1.

Table 1. The Mean SOD Enzyme Activity in Rat DMBA Treated by Extract of Roselle Calyx for 7 Days

\begin{tabular}{lc}
\hline \multicolumn{1}{c}{ Groups } & Mean activity SOD (Unit/mL) \pm SD \\
\hline Normal & $82.91 \pm 1.62^{\mathrm{a}}$ \\
Negative Control & $43.74 \pm 1.95^{\mathrm{b}}$ \\
Roselle extract $(10 \mathrm{mg} / \mathrm{kgBW})$ & $50.87 \pm 1.98^{\mathrm{c}}$ \\
Roselle extract $(50 \mathrm{mg} / \mathrm{kgBW})$ & $69.98 \pm 3.58^{\mathrm{d}}$ \\
Roselle extract $(100 \mathrm{mg} / \mathrm{kg} \mathrm{BW})$ & $73.01 \pm 6.95^{\mathrm{ad}}$ \\
\hline different symbol showed Significantly difference $; \mathrm{p}<0.05$
\end{tabular}

Enzyme activity of SOD in negative control group administered by DMBA (group II) decreased SOD activity significantly when compared with the normal group $(\mathrm{P} \leq 0.05)$ it is due to the activation of the 
enzyme cytochrome P-450 into a reactive intermediate produced the formation of epoxides dihidrodiol and radical cations [8] so that the significant decrease in SOD activity when compared with the normal group $(\mathrm{P} \leq 0.05)$ in the treatment group (group III , IV and V) were each given Roselle extract dose of 10 $\mathrm{mg} / \mathrm{kgBW} /$ day, $50 \mathrm{mg} / \mathrm{kg} \mathrm{BW} /$ day, and $100 \mathrm{mg} / \mathrm{kgBW} /$ day can increase the activity of SOD. Increasing activity of SOD in the treatment group III, IV, and V showed a significant difference to the group II (DMBA). The treatment dose of roselle extract $100 \mathrm{mg} / \mathrm{kg}$ BW/day showed the highest activity when compared with the treatment group III and IV.

Figure 1 shows that increasing doses of Roselle extract can increase the activity of SOD enzymes with dose dependent manner. This could be caused by the flavonoids contained in Roselle extract. The flavonoids could neutralize free radicals formed in the body allegedly through the mechanism of antioxidant capacity and the stimulation of the gene responsible for synthesis of antioxidant enzymes [9].

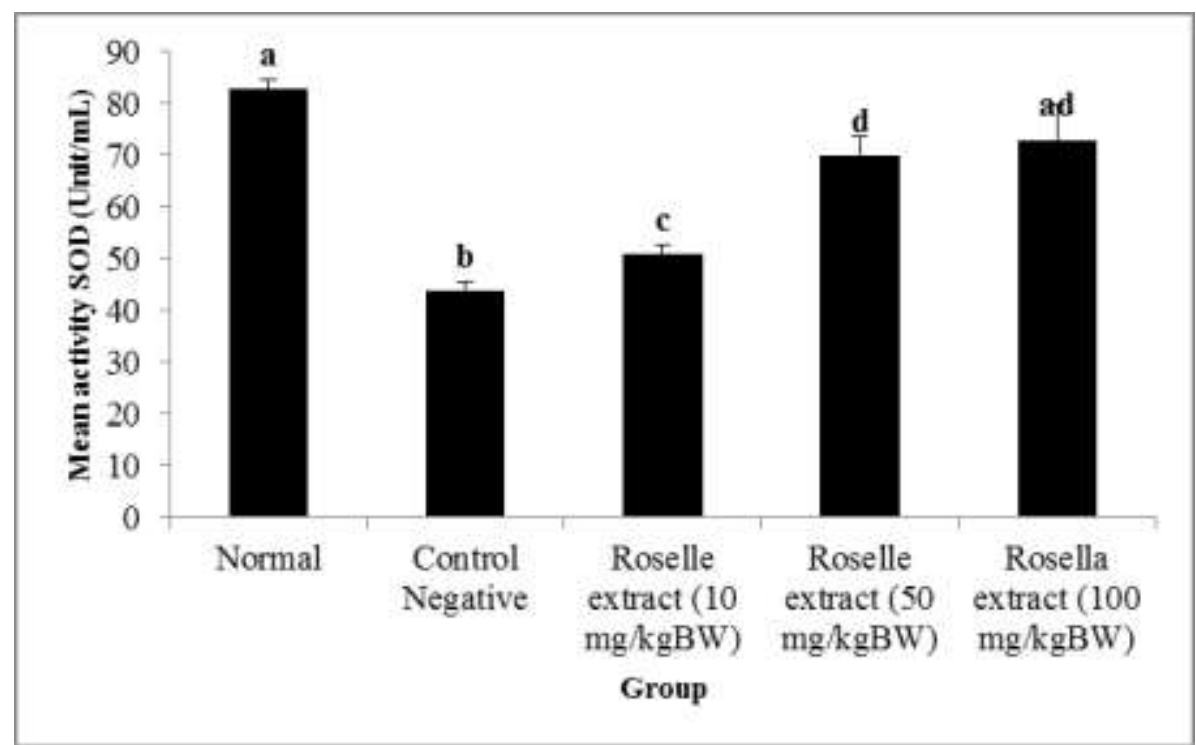

Note: Each group consisted of 5 rats. The same letter indicated no significant difference. The different letters indicate significant differences $(\mathrm{p}<0.05)$

Figure 1. The mean of activity SOD (units/mL) in the blood of rats induced by DMBA Roselle extract for 7 days

Mechanisms of flavonoids antioxidants in increasing SOD enzyme through the increasing levels of SOD in the liver caused by the phenolic component that induces the antioxidant enzyme genes [10]. Flavonoid activate the antioxidant receptor element (ARE) and induces DNA to produce antioxidant enzymes. Phenolic components in a suspected plant are capable of triggering expresion antioxidant genes such as Mn-SOD, Cu / Zn-SOD liver as shown in Figure 2.

Mann et al., (2007) describes the role of polyphenol in increasing of antioxidant activity through the activstion of ARE. Nitric oxide acts as a mediator of antioxidant enzymatic activation of gene transcription induced by isoflavones (flavonoid) [11]. Receptorr of flavonoid compounds bind to estrogen (ER) $\beta$ on the surface of the cell membrane then cascade reaction can activate the intracellular kinase, leading to rapidly produce eNOS activation and NO. Increased levels of NO or peroxynitrite will modify Keap cysteine residue in the protein-1 (Kelch ECH associating proteins) cause the release and translocation of the transcription factor Nrf2 to the nucleus. Nrf2 binds to the ARE (antioxidant receptor element) or by EpRE (electrophile response element) in the promoter region of target genes that can induce enzymatic antioxidant enzymes, such as SOD, GPx and NQ01 (NADPH quinine oxidoreductase 1).

Anthocyanins compound in the extract of Hibiscus sabdariffa $\mathrm{L}$ has the potential antioxidants in male albino rats induced by $\mathrm{CCl} 4$ [12]. The results of showed the potency of anthocyanin extract of Hibiscus sabdariffa as antioxidant and detoxification [12]. 


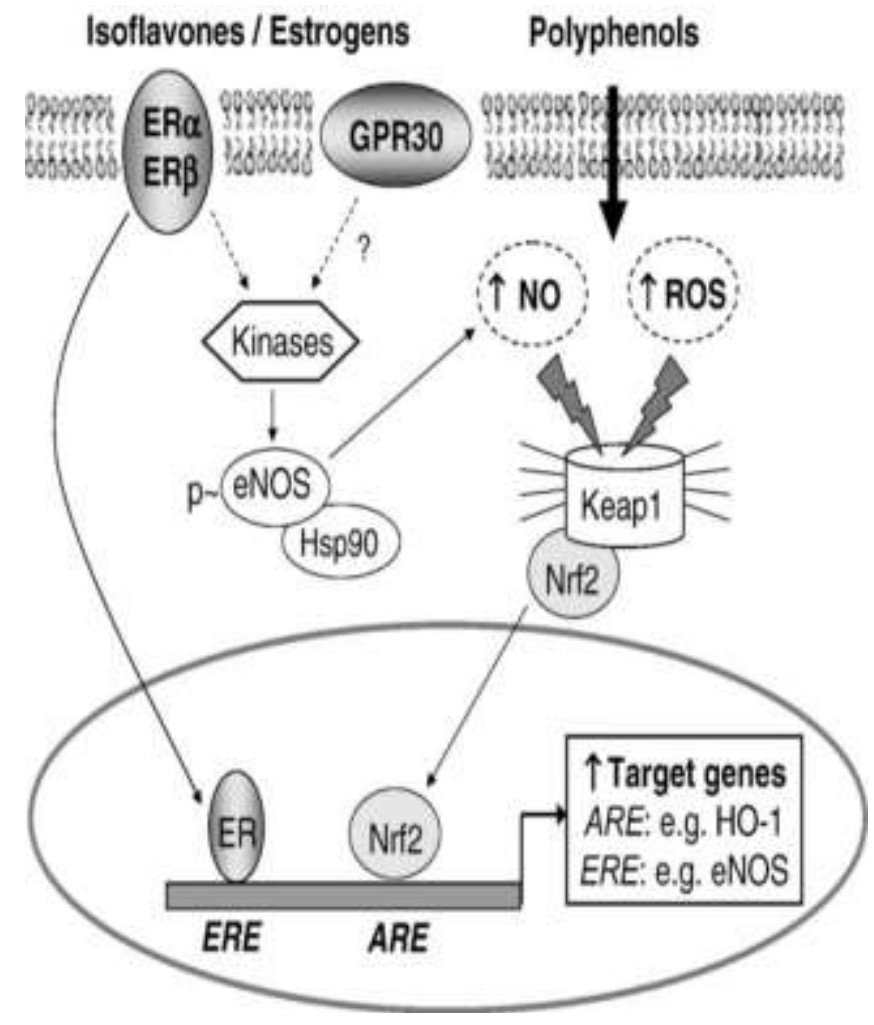

Figure 2. Nitric oxide as a mediator transcription activation of antioxidant genes induced by isoflavones [11]

\section{CONCLUSION}

Superoxide dismutase (SOD) is one of the primary antioxidants to inhibit free radicals. This research has studied ethanol extract of roselle calyx effect on SOD enzyme activity of the Sprague Dawley (SD) rats induced by 7.12-dimethylbenzen[a]anthracene (DMBA). Data analyze by using ANOVA and LSD $(\mathrm{P}<0.05)$ showed the significances on increasing of SOD activity at $10 \mathrm{mg} / \mathrm{kgBW}(50.87 \pm 1.98), 50$ $\mathrm{mg} / \mathrm{kgBW}(69.98 \pm 3.58)$ and $100 \mathrm{mg} / \mathrm{kgBW}(73.01 \pm 6.95)$ compared with DMBA $(43.74 \pm 1.95)(\mathrm{p}<0,05)$. It affirms that rosella extract can increase SOD enzyme activity.

\section{ACKNOWLEDGEMENTS}

The authors thank to Ministry of Higher Education of Indonesian Republic for funding the research through the Postgraduate Research Team Grant.

\section{REFERENCES}

[1] Cerutti, PA., "Okidant stress and carcinogenesis", Eur. J. Clin. Invest., vol. 21, pp. 1-11, 1991.

[2] Harman, D., "Free radical theory of aging, increasing the functional life span", Annals of The New York Academy of Sciences, vol. 717, pp. 1-15, 1994.

[3] Halliwell, R., Aruoma, OI., "DNA damage by oxygen-derived species”, FEBS Letters, vol. 281, pp. 9-19, 1991.

[4] Farombi, EO., Moller, P., Dragsted, LO., "Ex-vivo and in vivo protective effect of kolaviron againts oxygenderived radical-induced DNA damaged and oxidative stress in human lymphocytes and rat liver cells", Cell Biol Toxicol, vol/issue: 20(2), pp. 71-82, 2004.

[5] Wiyarsi, A., "Efficacy of Roselle (Hibiscus sabdariffa L)", http://staff.uny.ac.id/sites/default/files/tmp/PPM\%20Bunga\%20Rosella.pdf. Accessed on May 16, 2014

[6] Wijeratne, SSK., SL. Cuppett, V. Schlegel, "Hydrogen peroxide induced oxidative stress damage and antioxidant enzyme response in Caco-2 human colon cells", J.Agric.Food Chem, vol. 53, pp. 8768-8774, 2005.

[7] Young IS., JV., Woodside, “Antioxidant in Health and Disease”, Journal Clinical Pathology, 2013.

[8] Melendez-Colon, V., Luch, A., Seidel, A., Baird, WM., "Cancer Initiation by Polycyclic Aromatic Hydrocarbon Results from Formation of Stable DNA Adducts rather than Apurinic Sites", Carcinogenesis, vol/issue: 20(10), pp. 1885-1891, 1999.

[9] Simamora, A., "Flavonoid Antioxidants in Apples And Activity", Jakarta, UKRIDA, 2009. 
[10] Sugito, "Biological Antioxidant activity of Sorghum and barley And Its Application In Degenerative Disease Prevention", Journal of Human Development, vol. 6, pp. 1, 2012.

[11] Mann, GE., Rowlands DJ., Li FYL., de Winter P., Siow RCM., "Activation of Endhotelial Nitric Oxide Synthase by Dietary Isoflavones: Role of NO in Nrf2-Mediated Antioxidant Gene Expression”, Cardiovascular Res, vol. 75, pp. 261-274, 2007.

[12] Ajiboye, TO., Salawu, AK., Yakubu, MT., Oladiji, AT., Akanji, MA., Okogun, JI, “Antioxidant and drug detoxification potentials of Hibiscus sabdariffa anthocyanin extract", 2011. 